\title{
ASSESSING HEPATOPROTECTIVE EFFECTS OF ANTIOXIDANTS ON AMIODARONE-INDUCED CYTOTOXICITY IN HUMAN HEPATOMA HEPARG CELL LINE
}

Filimonova KS, Rogovskaya NYu, Beltyukov PP, Babakov VN区

Research Institute of Hygiene, Occupational Pathology and Human Ecology of the Federal Medical Biological Agency, Leningrad Region, Russia

\begin{abstract}
Effective therapy of amiodarone-induced hepatotoxicity requires studying the mechanisms of the toxic effects of amiodarone on hepatocytes and assessing the potential impact of hepotoprotective agents. The study was aimed to assess hepatoprotective effects of antioxidants on the amiodarone-induced hepatotoxicity with the use of immortalized human hepatoma cells of the HepaRG cell line. Cell viability was evaluated upon exposure to amiodarone and in the mixture with vitamin E, N-acetylcysteine and S-adenosylmethionine by impedance measurement; the levels of some hepatotoxicity biomarkers were defined using the Luminex xMAP technology. As a result of the research, the dose-dependent toxic effects of amiodarone were established. The $\mathrm{IC}_{50}$ value of amiodarone in the HepaRG cell line was $3.5 \mu \mathrm{M}$. It is shown that cytotoxic effects decrease and the $\mathrm{IC}_{50}$ value increases in the presence of vitamin $\mathrm{E}, \mathrm{N}$-acetylcysteine and $\mathrm{S}$-adenosylmethionine. Amiodarone reduces the activity of cell cycle regulators: AKT, JNK kinases, and p53 protein. Exposure to amiodarone results in reduced intracellular ATP levels and the release of intracellular enzymes (malate dehydrogenase 1, glutathione S-transferase, sorbitol dehydrogenase, 5'-nucleotidase) into conditioned medium, indicating the necrotic cell death. Thus, vitamin E, S-adenosylmethionine and N-acetylcysteine reduce amiodarone cytotoxicity in the model of amiodarone-induced damage to hepatocytes and can be considered as hepatoprotective agents in case of the need to protect liver against the hepatotoxic effects of amiodarone.
\end{abstract}

Keywords: HepaRG, amiodarone, drug hepatotoxicity, vitamin E, N-acetylcysteine, S-adenosylmethionine

$\triangle$ Correspondence should be addressed: Vladimir N. Babakov

Kapitolovo, 93, p/o Kuzmolovsky, Leningradskaja oblast, 188663; babakov@gpech.ru

Received: 20.07.2021 Accepted: 11.08.2021 Published online: 23.09.2021

DOI: $10.47183 /$ mes.2021.030

\section{ОЦЕНКА ГЕПАТОПРОТЕКТОРНОГО ЭФФЕКТА АНТИОКСИДАНТОВ НА АМИОДАРОН-ИНДУЦИРОВАННУЮ ЦИТОТОКСИЧНОСТЬ В КЛЕТКАХ ГЕПАТОМЫ ЧЕЛОВЕКА ЛИНИИ НЕРАRG}

\author{
К. С. Филимонова, Н. Ю. Роговская, П. П. Бельтюков, В. Н. Бабаков
}

Научно-исследовательский институт гигиены, профпатологии и экологии человека Федерального медико-биологического агентства,

Ленинградская область, Россия

\begin{abstract}
Для эффективной терапии амиодарон-индуцированной гепатотоксичности необходимы изучение механизмов токсического действия амиодарона на гепатоциты и оценка возможного влияния гепатопротекторов. Целью работы было исследовать гепатопротекторный эсфект антиоксидантов на амиодарон-индуцированную цитототоксичность с использованием иммортализованной гепатомы человека линии НераRG. Жизнеспособность клеток оценивали при действии амиодарона и в смеси с витамином E, N-ацетилцистеином и S-аденозилметионином методом импедансометрии, а также определяли содержание некоторых биомаркеров гепатотоксичности с использованием технологии Luminex xMAP. B результате исследования установлен дозозависимый эффект токсического действия амиодарона, IC I0 $_{50}$ амиодарона для линии НераRG составил 3,5 мкM. Показано, что в присутствии витамина E, N-ацетилцистеина и S-аденозилметионина снижается цитотоксический эффект и увеличивается значение IC ${ }_{50}$. Амиодарон снижает активность регуляторов клеточного цикла: киназ АКТ, JNK и белка р53. В результате действия амиодарона уменьшается содержание АТФ в клетках и наблюдается выход внутриклеточных ферментов (малатдегидрогеназы 1, глутатион-S-трансферазы, сорбитолдегидрогеназы, 5'-нуклеотидазы) в кондиционную среду, что свидетельствует о клеточной гибели по типу некроза. Таким образом, витамин E, S-аденозилметионин и N-ацетилцистеин снижают цитотоксичность амиодарона в модели амиодарон-индуцированного повреждения гепатоцитов и могут быть рассмотрены в качестве гепатопротекторов при необходимости защиты тканей печени от гепатотоксических эффектов амиодарона.
\end{abstract}

Ключевые слова: НераRG, амиодарон, лекарственная гепатотоксичность, витамин E, N-ацетилцистеин, S-аденозилметионин

$\triangle$ Для корреспонденции: Владимир Николаевич Бабаков

ст. Капитолово, к. 93, п. Кузьмоловский, Ленинградская область, 188663; babakov@gpech.ru

Статья получена: 20.07.2021 Статья принята к печати: 11.08.2021 Опубликована онлайн: 23.09.2021

DOI: $10.47183 /$ mes.2021.030

The symptoms of drug-induced liver injury constitute about $10 \%$ of adverse reactions, caused by medications, and are considered the main reason for clinical trial termination or for withdrawal of medications already used in therapy. Drugs of various pharmacological classes possess hepatotoxic effects: antibiotics (amoxicillin/clavulanate), analgesics (acetaminophen), antiepileptic drugs (valproate), etc. [1].

Drug dosage reduction or permanent discontinuation of the drug allows for prevention of irreversible liver damage. However, in some cases it is necessary to continue using hepatotoxic drug in parallel with the use of hepatoprotective drugs. The efficiency of hepatoprotective drugs used in clinical practice results from the presence of components, having various mechanisms of action. There remains a need for developing new pharmaceutical products to protect the liver against the possible toxic effects, since hepatoprotective drugs are not always able to minimize the adverse effects of xenobiotics, and the use of specific antidotes is limited to the use of $\mathrm{N}$-acetylcysteine in paracetamol overdose [2]. Developing the efficient methods for the drug-induced liver injury treatment requires studying the toxin-induced hepatic cell damage mechanisms, and selecting the potential hepatoprotective agents and specific antidotes.

Amiodarone, being the anti-arrhythmic agent, is characterized by the frequent side effects, manifested by the symptoms of drug-induced liver injury. Amiodarone is one of the most frequently prescribed anti-arrhythmic medication due to high efficiency and broad spectrum of action [3].

In $10-15 \%$ of cases, administration of amiodarone is compounded by side effects in the form of elevated serum 
transaminase levels, phospholipidosis and steatohepatitis. The long-term use of amiodarone may result in acute liver failure, which is sometimes fatal [4].

Liver injury, resulting from administration of amiodarone, is due to cytotoxic effects of the medication. It is known that amiodarone and its metabolites (mostly mono- and di$\mathrm{N}$-desethylamiodarone) inhibit the electron transport chain function and uncouple oxidative phosphorylation, which should be complemented by the reactive oxygen species accumulation and the development of oxidative stress $[5,6]$. Oxidative stress is indicated by the elevated lipid peroxidation marker levels after exposure to amiodarone [7]. Furthermore, amiodarone is able to inhibit phospholipase $A$ and $\beta$-oxidation of long-chain fatty acids, which promotes lipid accumulation in hepatic cells [8, 9]. There is also a decline in the intracellular ATP levels and calcium ions; endoplasmic reticulum is damaged [10].

Earlier, the study involving the L929 mouse fibroblast cell line showed that the use of antioxidant agents, vitamin $\mathrm{C}$ and $\mathrm{N}$-acetylcysteine, contributed to reduced amiodarone cytotoxicity [11]. We have studied the ability of nonspecific hepatoprotective compounds, possessing antioxidant activity (vitamin $\mathrm{E}$ and the sulfur-containing $\mathrm{N}$-acetylcysteine and S-adenosylmethionine), to affect cytotoxic properties of amiodarone.

Vitamin $\mathrm{E}$ has long been known as a cytoprotective agent and recommended for therapy of inflammatory and degenerative liver diseases, such as non-alcoholic fatty liver disease and steatohepatitis [12]. N-acetyl-L-cysteine (NAC) is the effective antidote to treat paracetamol overdose. NAC is also proposed to be used in management of non-paracetamol drug-induced

A

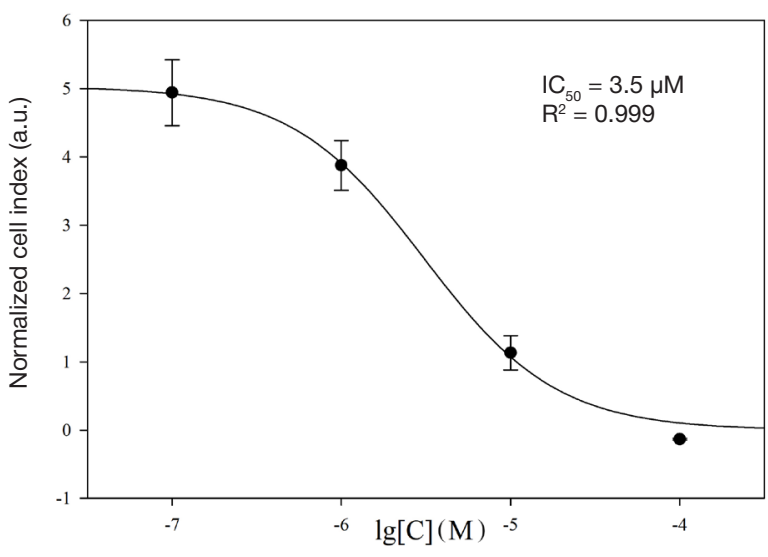

C

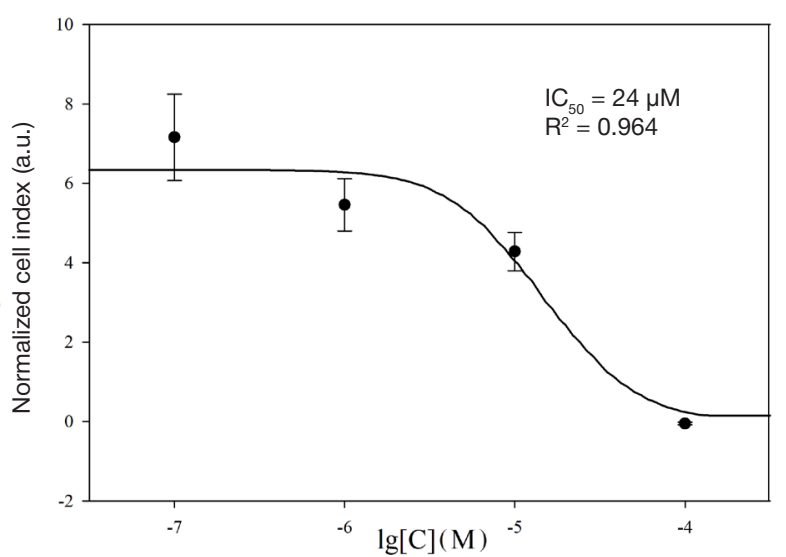

liver injury [13]. S-adenosyl-L-methionine (SAM) is the main donor of methyl groups in the body, it also plays an important role in the xenobiotic metabolism in the liver. Therefore, SAM is also viewed as a hepatoprotective agent for various liver diseases. However, in clinical practice, hepatoprotective effects of SAM has not been supported by randomized placebocontrolled trials [14].

Test systems based on primary human hepatocyte culture or immortalized cell lines are used for in vitro investigation of cytotoxic effects on hepatocytes. During the study, we used the human hepatoma HepaRG cell line. Cells of this cell line ensure the expression of biotransformation enzymes (in particular, cytochromes P450) and transport proteins at the levels close to those of primary human hepatocytes. This gives us ground to consider this cell line to be the optimal choice for in vitro hepatotxicity modeling $[15,16]$. The HepaRG cell line has shown maximum sensitivity in assessing the potential hepatotoxicity of medications with the use of multiparametric assay $[17,18]$.

Thus, the study was aimed to assess cytoprotective effects of antioxidants in the human hepatoma HepaRG cell line-based model of amiodarone-induced cytotoxicity.

\section{METHODS}

Human hepatoma cells of the HepaRG cell line (Gibco; USA) were cultured in the complete growth medium, consisting of William's E medium with $10 \%$ fetal bovine serum, $5 \mu \mathrm{g} / \mathrm{mL}$ of insulin, $10 \mathrm{U} / \mathrm{mL}$ of penicillin, $100 \mu \mathrm{g} / \mathrm{mL}$ of streptomycin, $50 \mu \mathrm{M}$ of hydrocortisone hemisuccinate, and $2 \mathrm{mM}$ of L-glutamine, in

B

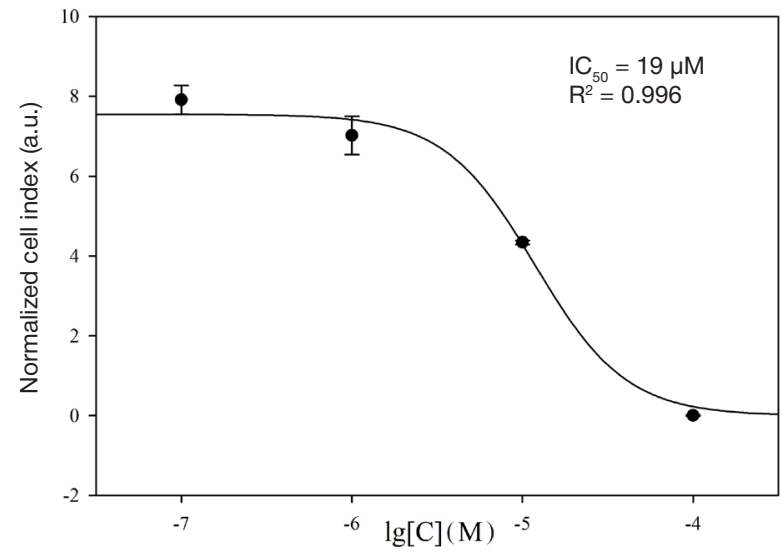

D

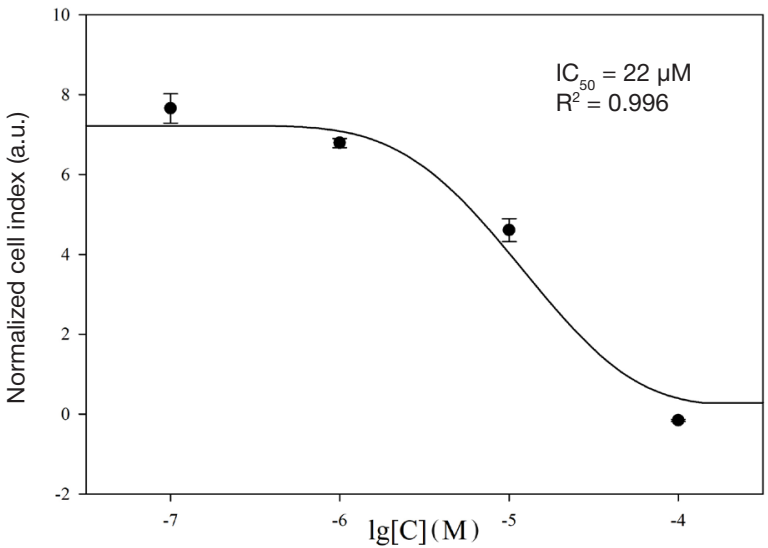

Fig. 1. Relationship between cell index of HepaRG cells and log concentration of amiodarone (cell index has been normalized in terms of the time when the medium containing the studied substance has been added). A. Changes in cell index upon exposure to amiodarone at a concentration of $0.1,1,10$ and $100 \mu \mathrm{M}$. B. Changes in cell index upon exposure to amiodarone dilution series in the presence of $100 \mathrm{\mu M}$ of vitamin $\mathrm{E}$. C. Changes in cell index upon exposure to amiodarone dilution series in the presence of $100 \mu \mathrm{M}$ of $\mathrm{N}$-acetylcysteine. D. Changes in cell index upon exposure to amiodarone dilution series in the presence of $100 \mu \mathrm{M}$ of S- adenosylmethionine 

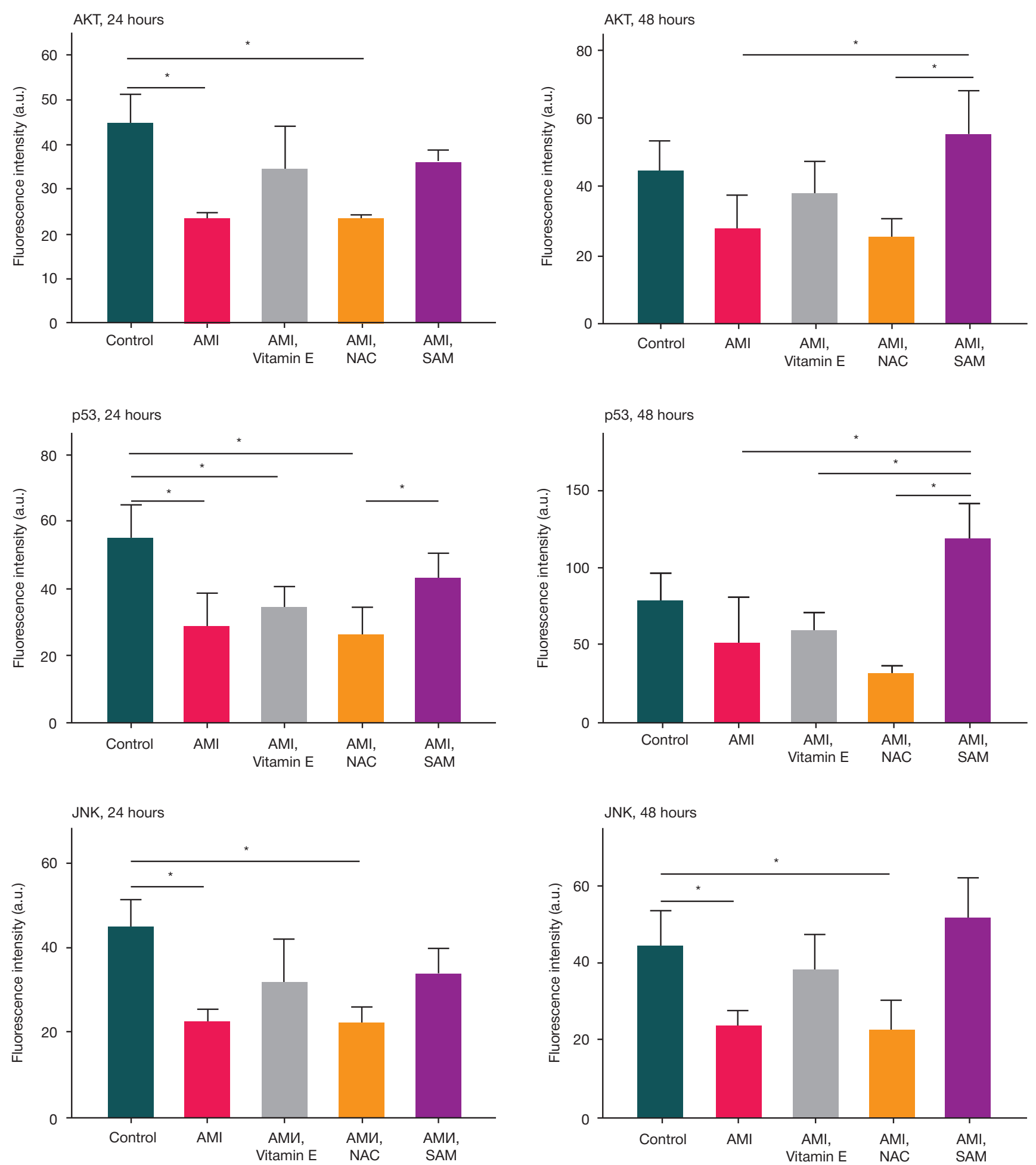

Fig. 2. Phosphorylated AKT kinase (Ser473), p53 protein (Ser46), JNK kinase (Thr183/Tyr185) fluorescence intensity in the HepaRG cell lysates after exposure to amiodarone at a concentration of $10 \mu \mathrm{M}$ (AMI), and against the effects of $100 \mu \mathrm{M}$ of vitamin $\mathrm{E}, 100 \mu \mathrm{M}$ of $\mathrm{N}$-acetylcysteine (NAC), $100 \mu \mathrm{M}$ of S-adenosylmethionine (SAM) during the 24- and 48-hour incubation. * $-p<0.05$

the atmosphere of $\mathrm{CO}_{2}$ incubator $\left(5 \% \mathrm{CO}_{2}\right)$ at a temperature of $37^{\circ} \mathrm{C}$ and saturation humidity.

The xCELLigence RTCA system (ACEA; USA) was used to define amiodarone cytotoxicity. Cell index, being the indicator of cell viability, was calculated with the RTCA Software 2.0 (ACEA; USA) based on the analysis of changes in impedance over time. Prior to the experiment, the impedance of the growth medium in the absence of cells was measured. Next, a total of 10,000 HepaRG cells were added to each well of the 96-well plate and cultured for 24 hours. After that amiodarone (at a concentration of $0.1-100 \mu \mathrm{M}$ ) and studied antioxidants (vitamin E, NAC and SAM at a concentration of $100 \mu \mathrm{M}$ ) were added to the medium. Cells cultured in complete growth medium were used as a control.

Molecular markers of cell damage were assessed with the Bio-Plex 200 suspension array system (Bio-Rad; USA). Markers of apoptosis were assessed in cell lysates, and markers of hepatocyte damage were assessed in conditioned media. In order to obtain conditioned media and lysates, human hepatoma cells of the HepaRG cell line were added to the 24-well plate 


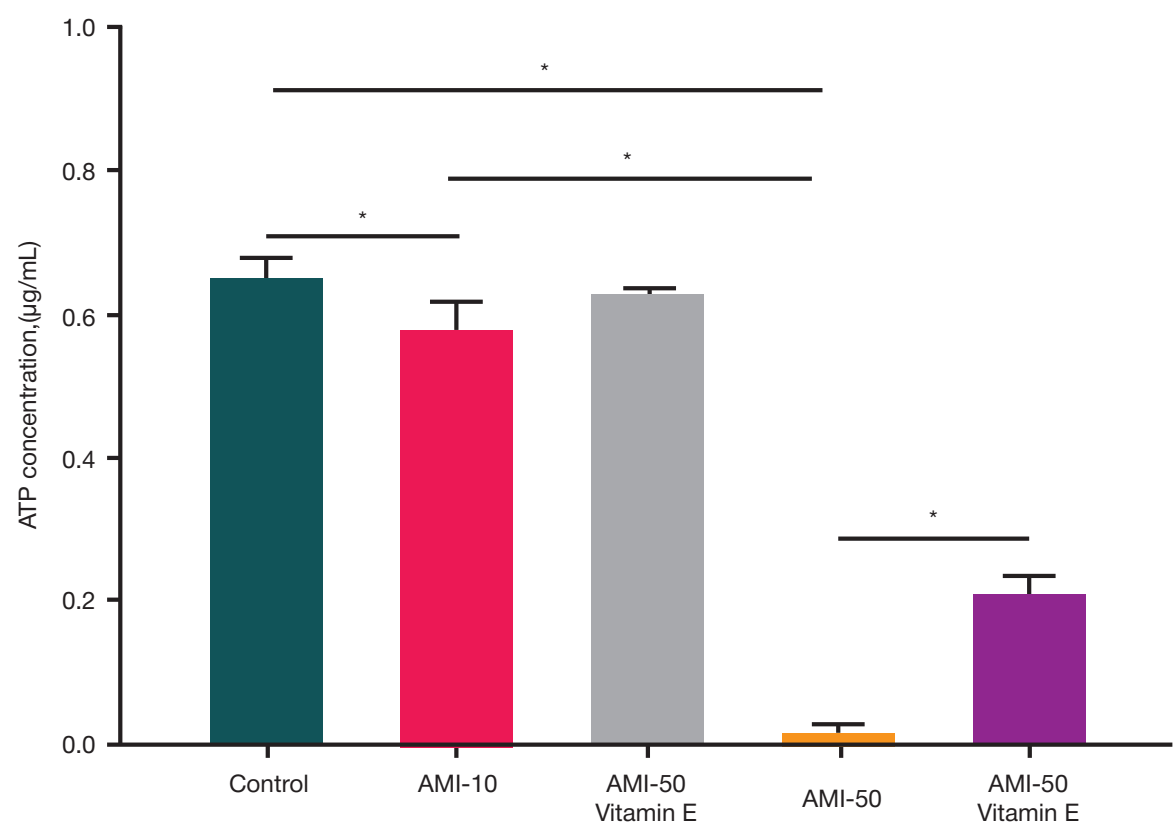

Fig. 3. ATP levels in HepaRG cell lysates after the 24-hour exposure to amiodarone at a concentration of $10 \mu \mathrm{M}(\mathrm{AMI}-10)$ and $50 \mu \mathrm{M}(\mathrm{AMI}-50)$ against the background of exposure to vitamin $\mathrm{E}$. $-p<0.05$

(400,000 cells per well) and cultured in the complete growth medium. The next day after passage, the medium was replaced with the medium, containing amiodarone at a concentration of $10 \mu \mathrm{M}$ together with the studied antioxidants at a concentration of $100 \mu \mathrm{M}$. The samples were incubated for 24 and 48 hours. Each experimental concentration of the studied substances was added in at least three iterations. The following kits were used for the multiplex analysis: MILLIPLEX MAP Human Liver Injury Magnetic Bead Panel (Cat. HLINJMAG-75K; Merck, USA), MILLIPLEX MAP Human Early Apoptosis Magnetic Bead 6-Plex Kit (Cat. 48-669MAG; Merck, USA), and Bio-PlexPro ${ }^{\mathrm{TM}}$ Human Cytokine 27-plex Screening Panel (Cat. M500KCAFOY; Bio-Rad, USA).

ATP was assessed in the HepaRG cell lysates using the ATP Bioluminescent Assay Kit (Cat. FLASC; Sigma-Aldrich, USA). The intensity of luminescent emission was measured with the FLx800 Microplate Fluorescence Reader (BioTek; USA). Data preprocessing was performed with the Gen5 1.10 software (BioTek; USA).

Statistical analysis and charting were carried out using the SigmaPlot 12.5 software (SystatSoftware Inc; USA). The sample was tested for normality with the Shapiro-Wilk test. The significance of differences between means was assessed by univariate analysis of variance for normal distributions and Kruskal-Wallis test for distributions other than normal. The differences were considered significant when $p<0.05$. The results were presented as mean \pm standard deviation.

\section{RESULTS}

The $I C_{50}$ value, calculated based on the monitoring of amiodarone cytotoxicity for the human hepatoma cells of the HepaRG cell line, was $3.5 \mu \mathrm{M}$ (Fig. 1). The use of hepatoprotective agents, possessing antioxidant activity, resulted in significantly increased cell index compared to amiodarone. Thus, the $\mathrm{IC}_{50}$ value obtained for amiodarone in the presence of vitamin $E$ was $19 \mu \mathrm{M}$; the value for $\mathrm{N}$-acetylcysteine was $24 \mu \mathrm{M}$, and the value for S-adenosylmethionine was $22 \mu \mathrm{M}$.

The levels of some kinases involved in the cell cycle regulation in cell lysates, and the levels of intracellular enzymes in the conditioned media were analyzed in order to assess the mechanisms of cytotoxicity. The exposure of cells to amiodarone $(10 \mu \mathrm{M})$ during 24 and 48 hours resulted in reduced levels of phosphorylated AKT and JNK kinases together with the p53 protein (Fig. 2). In other words, amiodarone contributes the decreased activity of enzymes, involved in the cell cycle regulation, and triggers cell death. This can explain high cytotoxicity of amiodarone. The levels of AKT and JNK kinase active forms in the cell lysates after treating with amiodarone $(10 \mu \mathrm{M})$ in the presence of vitamin $\mathrm{E}$ or S-adenosylmethionine were the same as in control samples.

The study found that amiodarone concentrations of 10 and $50 \mu \mathrm{M}$ caused a significant decline in the ATP levels in the HepaRG cell lysates; the decline in the ATP levels was dose dependent (Fig. 3). Vitamin E provided a significant increase in the intracellular ATP levels upon amiodarone cell treatment.

Assessment of extracellular enzyme levels showed that there was no significant increase in the levels of arginase 1 after treating cells with amiodarone (Fig. 4). After the 24 hour incubation with amiodarone, elevated levels of malate dehydrogenase 1, glutathione S-transferase and sorbitol dehydrogenase in the conditioned medium were observed (Fig. 4, 5). The levels of 5'-nucleotidase significantly increased in 48 hours. In the presence of vitamin $\mathrm{E}$ and S-adenosylmethionine, decline in the levels of MDH1, GST $\alpha$ and SDH intracellular enzymes in the conditioned medium was detected.

Analysis of cytokine levels after the HepaRG line cells' incubation in the medium with amiodarone $(10 \mu \mathrm{M})$ showed the significant and the most prominent increase in the levels of IL1 $\beta$, IL6, IL8, IFN $\gamma$, TNF $\alpha$ pro-inflammatory factors, resulting from exposure to amiodarone (Fig. 6). At the same time, elevated levels of anti-inflammatory cytokine IL10 were noted. The effects of antioxidants were reflected in the reduced levels of the assessed cytokines in the conditioned media.

\section{DISCUSSION}

Side effects of amiodarone were reported in the late $20^{\text {th }}$ century, after the beginning of its widespread use as an antiarrhythmic agent [19]. Based on its structure, amiodarone belongs to the class of cationic amphiphilic substances. Moreover, amiodarone has a long half-life in the terminal elimination phase, which can 

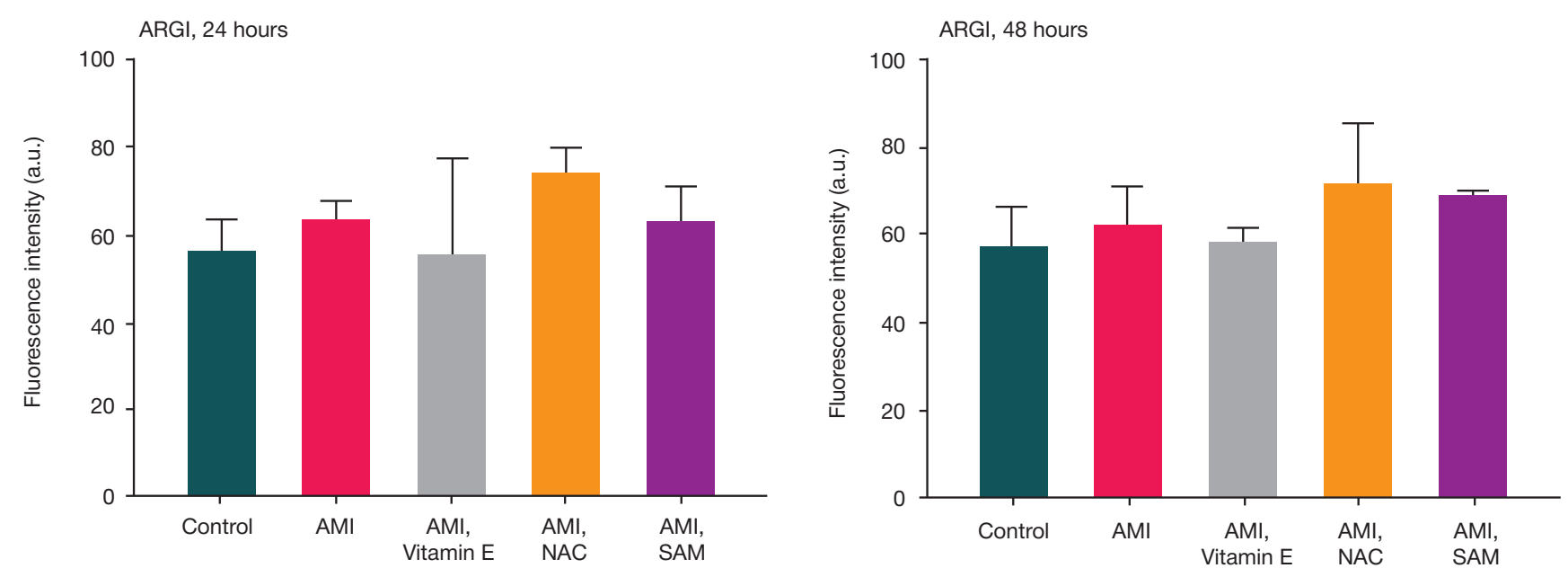

$\mathrm{MDH} 1,24$ hours
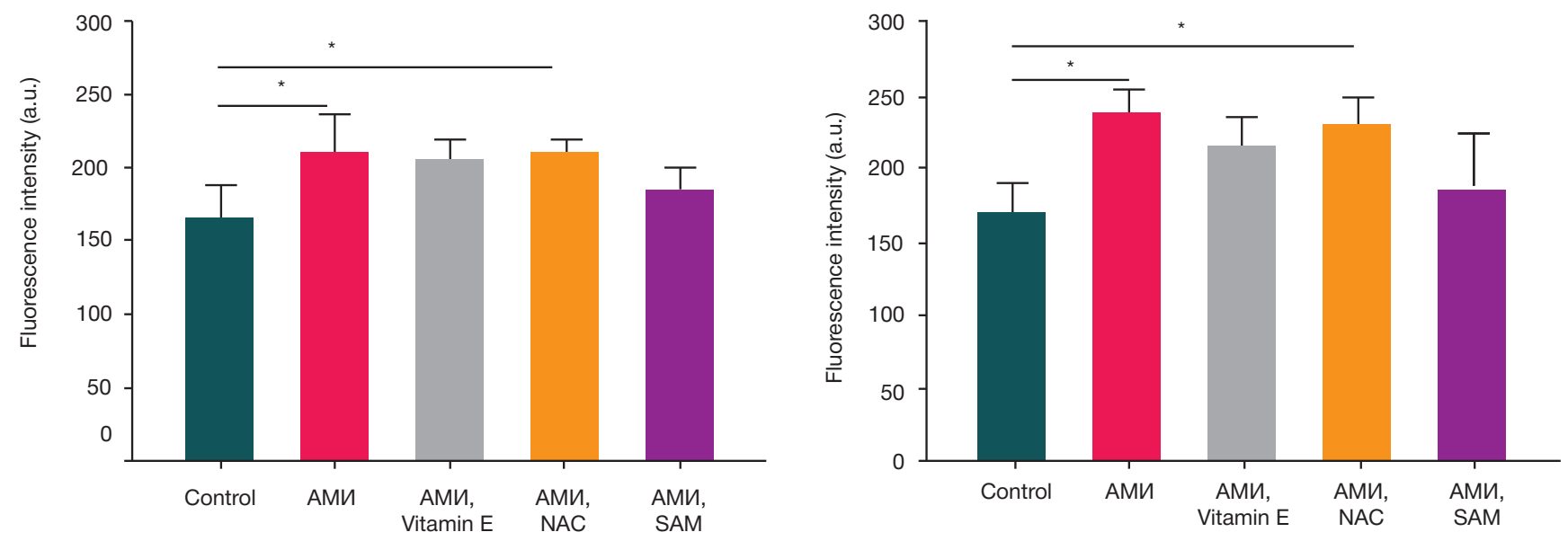

GSTa, 24 hours
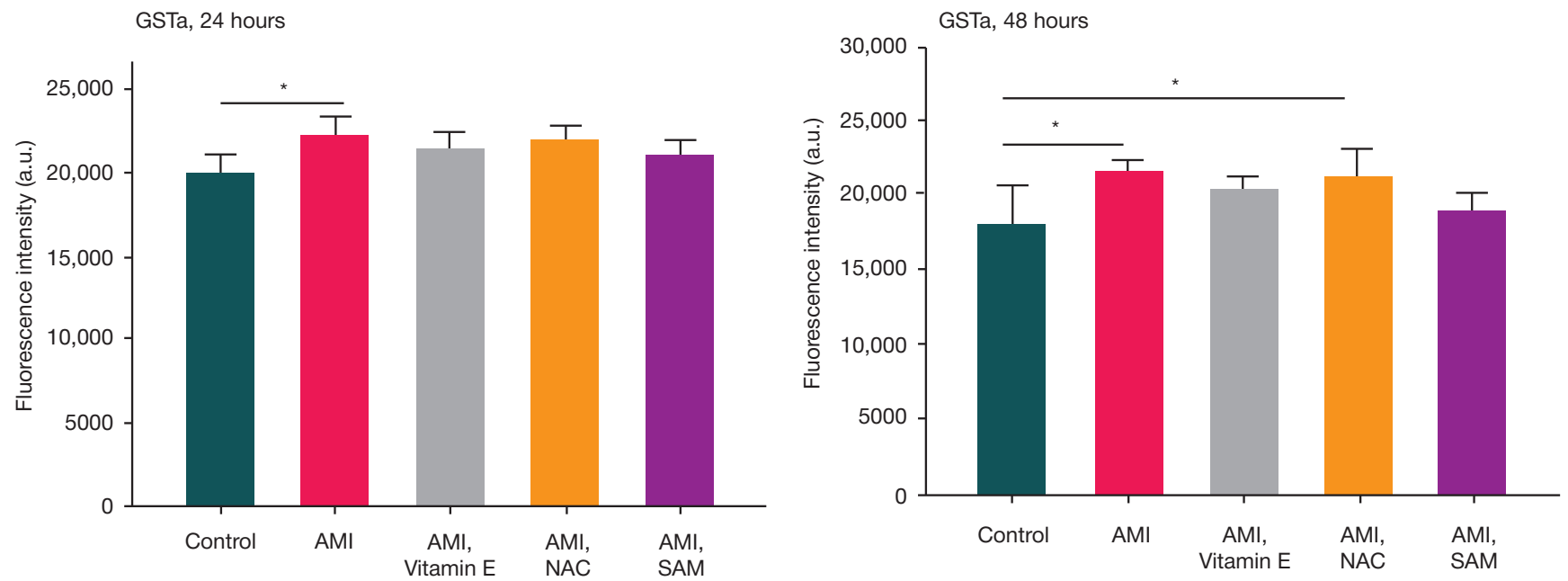

Fig. 4. Arginase 1 (ARG1), malate dehydrogenase 1 (MDH1), glutathione S-transferase (GST $\alpha$ ) fluorescence intensity in the conditioned medium of the HepaRG cells after exposure to amiodarone at a concentration of $10 \mu \mathrm{M}$ (AMl), and against the effects of $100 \mu \mathrm{M}$ of vitamin $\mathrm{E}, 100 \mu \mathrm{M}$ of $\mathrm{N}$-acetylcysteine (NAC), $100 \mu \mathrm{M}$ of S-adenosylmethionine (SAM) during the 24- and 48-hour incubation. * $-p<0.05$

be up to 150 days [8]. Amiodarone and its metabolites can accumulate in lungs, skeletal muscles, adipose tissue, liver, and exhibit toxic effects. Meanwhile, the degree of liver injury varies significantly from slightly increased serum transaminase levels to acute liver failure [4].

The long-term oral (per os) administration of amiodarone results in accumulation of fatty acids and polar lipids in hepatocytes due to inhibition of phospholipase A and enzymes for $\beta$-oxidation of fatty acids. Accumulation of amiodarone in Iysosomal lipid bilayers has been reported, which interferes with the normal intracellular degradation of membrane phospholipids and results in phospholipidosis [8, 20]. Accumulation of triglycerides and lipid droplets after the 14-day incubation of the human hepatoma HepaRG cell line with amiodarone at a concentration of $20 \mu \mathrm{M}$ has been reported [21].

However, the mechanisms of amiodarone-induced hepatotoxicity are still poorly understood.

We defined the dose-dependent cytotoxic effects of amiodarone on the HepaRG cell line for three days and calculated the $\mathrm{IC}_{50}$ value, which was $3.5 \mu \mathrm{M}$. Earlier, amiodarone 
$5-N T, 24$ hours

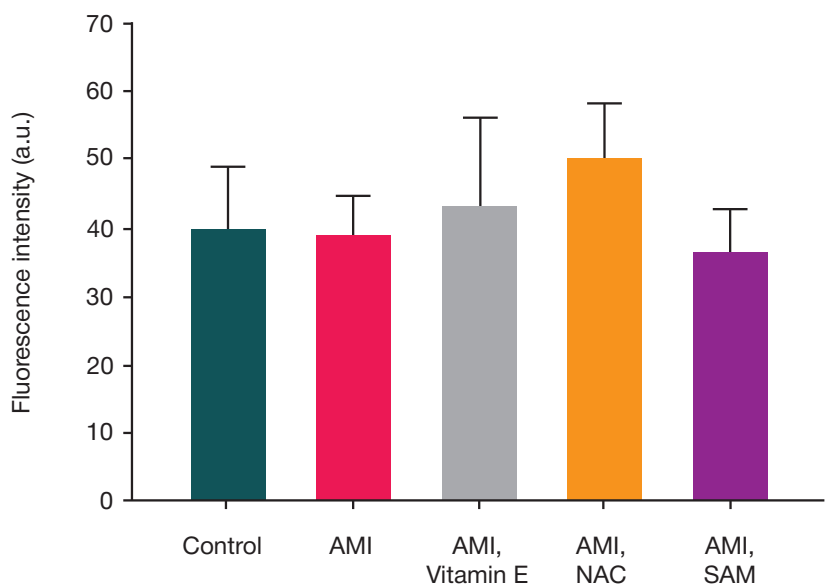

$\mathrm{SDH}, 24$ hours

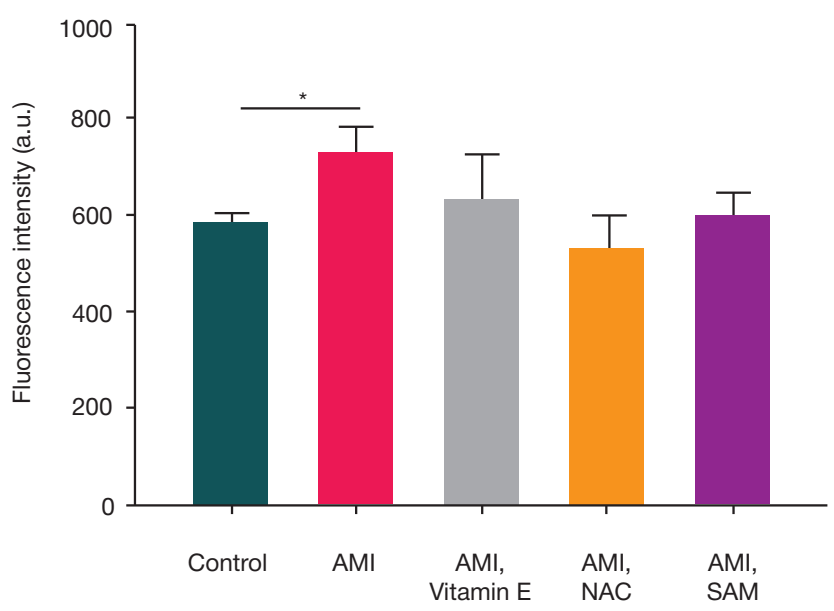

5-NT, 48 hours

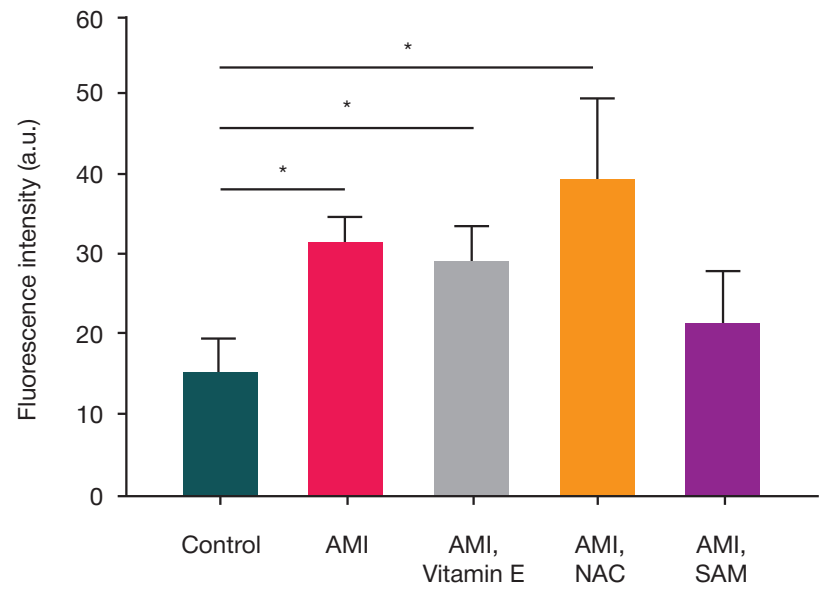

$\mathrm{SDH}, 48$ hours

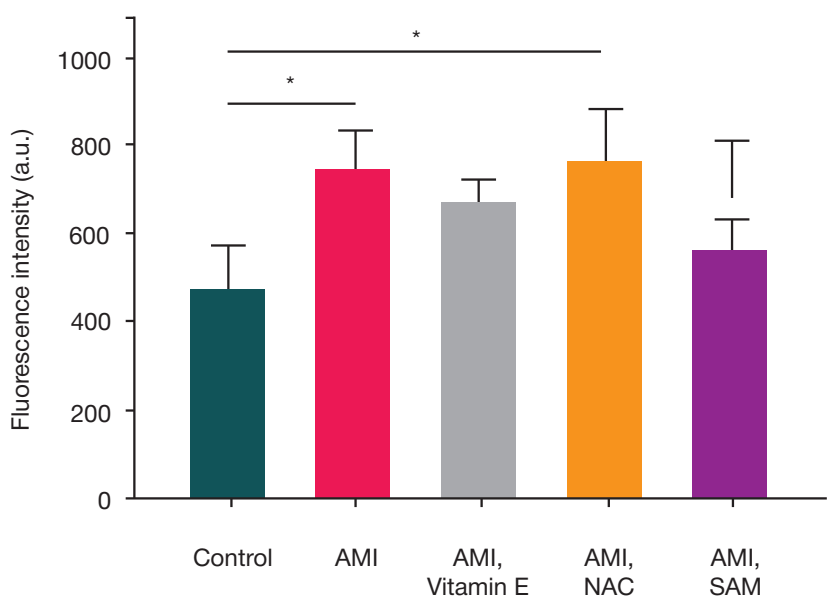

Fig. 5. Nucleotidase (5'-NT), sorbitol dehydrogenase (SDH) fluorescence intensity in the conditioned medium of the HepaRG cells after exposure to amiodarone at a concentration of $10 \mu \mathrm{M}(\mathrm{AMI})$, and against the effects of $100 \mu \mathrm{M}$ of vitamin E, $100 \mu \mathrm{M}$ of N-acetylcysteine (NAC), $100 \mu \mathrm{M}$ of S-adenosylmethionine (SAM) during the 24- and 48-hour incubation. * $-p<0.05$

cytotoxicity was demonstrated during the study, involving the HepG2 cell line, where the $\mathrm{IC}_{50}$ value was $105 \mu \mathrm{M}[7]$. However, HepaRG cells show higher expression of the cytochrome P450 system enzymes compared to the HepG2 cell line. Amiodarone metabolites (mono- and di-N-desethylamiodarone), formed after transformation by cytochromes, can exhibit higher hepatotoxicity compared to amiodarone [18].

The increased intracellular levels of active (phosphorylated) forms of kinases, involved in the cell cycle regulation, indicate the type of cell death and the pathways of cell death process activation [22]. During our study, exposure to amiodarone resulted in reduced levels of active forms of AKT and JNK kinases and p53 protein. This indicates that mitochondrial damage is the main mechanism, triggering cell death when exposed to amiodarone. The levels of active initiator caspase- 8 are also reduced after threating cell culture with amiodarone, which makes it possible to speak of necrotic cell death instead of apoptosis.

It is known that intracellular levels of ATP are the measure of cell viability [23]. Depletion of intracellular ATP reserves is considered one of the characteristic features of necrosis [24]. The detected decline in intracellular ATP levels, and the release of intracellular enzymes into conditioned medium also demonstrate the necrotic cell death.

It has been also found that exposure to amiodarone results in elevated levels of pro-inflammatory cytokines IL1 $\beta$, IL6, IL8, IFN $\gamma$, TNF $\alpha$ and anti-inflammatory cytokine IL10 in the conditioned medium.
Intracellular enzymes, cytokines and danger associated molecular patterns (DAMPs), released when the cells are damaged, activate the innate immunity cells [25]. Activated Kupffer cells and neutrophils together with other resident liver cells secrete various cytokines, which can result in triggering apoptosis through death receptors and the development of inflammatory response [22]. Thus, the exposure to amiodarone may cause both necrosis and apoptosis, which is consistent with the previously published data on cytostatic effects of amiodarone [26, 27].

Thus, the human hepatoma HepaRG cell line model has shown that cell death, occurring after the 48-hour exposure to amiodarone, is the result of necrosis.

It is anticipated that oxidative stress is one of the root causes of amiodarone cytotoxicity [7]. Earlier, with the use of various cell models (primary rat hepatocytes, HepG2, L929 cells), it has been shown that antioxidants protect cells against cytotoxic effects of amiodarone [7, 11, 28]. We have assessed the impact of compounds with antioxidant properties on the amiodarone-induced cytotoxicity in the human hepatoma cells of the HepaRG cell line. Vitamin E, S-adenosylmethionine and $\mathrm{N}$-acetylcysteine reduce cytotoxicity of amiodarone and increase the $\mathrm{IC}_{50}$ value. Vitamin $\mathrm{E}$ and $\mathrm{S}$-adenosylmethionine ensure amiodarone-induced reduction of the key proinflammatory IL1 $\beta$ and IL6 cytokine secretion.

The listed above results confirm that amiodarone is able to induce oxidative stress in cells. The studied vitamin E, 

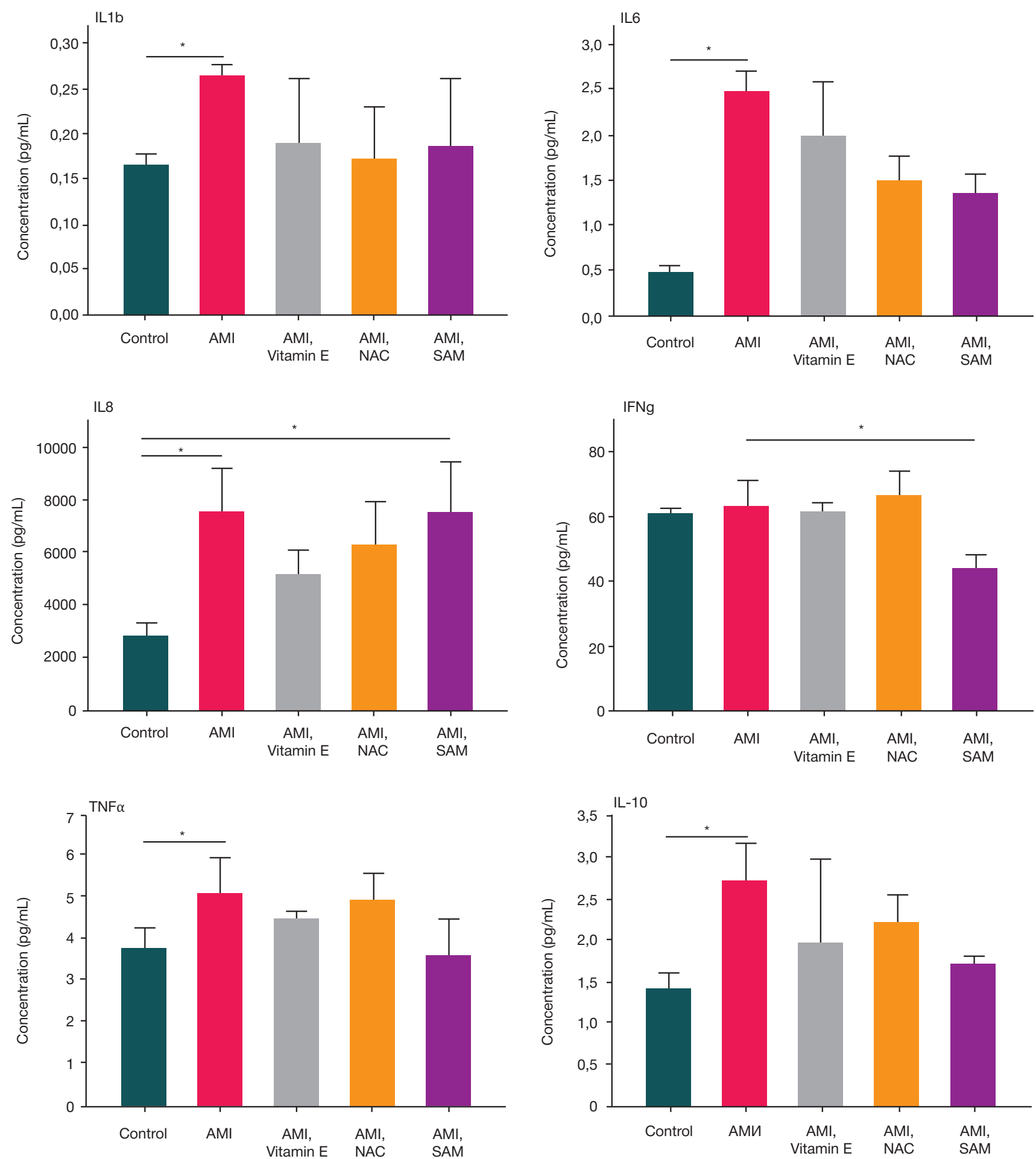

Fig. 6. Concentration of cytokines IL1 $\beta, I L 6, I L 8, I F N \gamma$, TNF $\alpha$ and IL10 in the conditioned medium of HepaRG cells, incubated during 48 hours and exposed to amiodarone at a concentration of $10 \mu \mathrm{M}$ (AMI), and against the effects of $100 \mu \mathrm{M}$ of vitamin $\mathrm{E}, 100 \mu \mathrm{M}$ of $\mathrm{N}$-acetylcysteine (NAC), $100 \mu \mathrm{M}$ of S-adenosylmethionine (SAM). * $-p<0.05$

S-adenosylmethionine and $\mathrm{N}$-acetylcysteine are the registered medicinal products and could be recommended as hepatoprotective agents during amiodarone therapy.

\section{CONCLUSIONS}

Amiodarone has a cytotoxic effect on the human hepatoma cells of the HepaRG cell line $\left(\mathrm{IC}_{50} 3.5 \mu \mathrm{M}\right)$. Cell death occurs with underlying reduction in the levels of active forms of factors, involved in cell cycle regulation, such as AKT, JNK kinases, and p53 protein. The effects of amiodarone result in cytolysis accompanied by the increase in the levels of intracellularenzymes (MDH1, GST $\alpha, S D H$ and 5'-NT) in the conditioned medium. The studied compounds possessing antioxidant properties, Vitamin E, N-acetylcysteine and S-adenosylmethionine, reduce amiodarone-induced cytotoxicity in the human hepatoma cells of the HepaRG cell line and can be considered as potential hepatoprotective agents during treatment with amiodarone. 
1. Ivashkin VT, Baranovsky AYu, Raikhelson KL, i dr. Lekarstvennye porazhenija pecheni (klinicheskie rekomendacii dlja vrachej). Rossijskij zhurnal gastrojenterologii, gepatologii, koloproktologii. 2019; 29 (1): 101-31. Russian.

2. Stine JG, Lewis JH. Current and future directions in the treatment and prevention of drug-induced liver injury: a systematic review. Expert Rev Gastroenterol Hepatol. 2016; 10 (4): 517-36.

3. Mujović N, Dobrev D, Marinković M, et al. The role of amiodarone in contemporary management of complex cardiac arrhythmias. Pharmacol Res. 2020; 151: 104521

4. Hashmi A, Keswani NR, Kim S, et al. Hepatic dysfunction in patients receiving intravenous amiodarone. South Med J. 2016; 109 (2): 83-6.

5. Waldhauser KM, Török M, Ha H-R, et al. Hepatocellular toxicity and pharmacological effect of amiodarone and amiodarone derivatives. J Pharmacol Exp Ther. 2006; 319 (3): 1413-23.

6. Serviddio G, Bellanti F, Giudetti AM, et al. Mitochondrial oxidative stress and respiratory chain dysfunction account for liver toxicity during amiodarone but not dronedarone administration. Free Radic Biol Med. 2011; 51 (12): 2234-42.

7. Golli-Bennour EE, Bouslimi A, Zouaoui O, et al. Cytotoxicity effects of amiodarone on cultured cells. Exp Toxicol Pathol. 2012; 64 (5): 425-30.

8. Schumacher JD, Guo GL. Mechanistic review of drug-induced steatohepatitis. Toxicol Appl Pharmacol. 2015; 289 (1): 40-7.

9. Grünig D, Duthaler U, Krähenbüh S. Effect of Toxicants on Fatty Acid Metabolism in HepG2 Cells. Front Pharmacol. 2018; 9: 257.

10. Erez N, Hubel E, Avraham R, et al. Hepatic amiodarone lipotoxicity is ameliorated by genetic and pharmacological inhibition of endoplasmatic reticulum stress. Toxicol Sci. 2017; 159 (2): 402-12.

11. Durukan AB, Erdem B, Durukan E, et al. May toxicity of amiodarone be prevented by antioxidants? A cell-culture study. J Cardiothorac Surg. 2012; 7 (1): 61.

12. Galli F, Azzi A, Birringer M, et al. Vitamin E: Emerging aspects and new directions. Free Radic Biol Med. 2017; 102: 16-36.

13. Chughlay MF, Kramer N, Spearman CW, et al. N-acetylcysteine for non-paracetamol drug-induced liver injury: a systematic review. Br J Clin Pharmacol. 2016; 81: 1021-9.

14. Anstee QM, Day CP. S-adenosylmethionine (SAMe) therapy in liver disease: A review of current evidence and clinical utility. J Hepatol. 2012; 57 (5): 1097-109.

15. Aninat C, Piton A, Glaise D, et al. Expression of cytochromes

\section{Литература}

1. Ивашкин В. Т., Барановский А. Ю., Райхельсон К. Л.и др. Лекарственные поражения печени (клинические рекомендации для врачей). Российскийжурналгастроэнтерологии, гепатологии, колопроктологии. 2019; 29 (1): 101-31.

2. Stine JG, Lewis JH. Current and future directions in the treatment and prevention of drug-induced liver injury: a systematic review. Expert Rev Gastroenterol Hepatol. 2016; 10 (4): 517-36.

3. Mujović $\mathrm{N}$, Dobrev D, Marinković $\mathrm{M}$, et al. The role of amiodarone in contemporary management of complex cardiac arrhythmias. Pharmacol Res. 2020; 151: 104521

4. Hashmi A, Keswani NR, Kim S, et al. Hepatic dysfunction in patients receiving intravenous amiodarone. South Med J. 2016; 109 (2): 83-6.

5. Waldhauser KM, Török M, Ha H-R, et al. Hepatocellular toxicity and pharmacological effect of amiodarone and amiodarone derivatives. J Pharmacol Exp Ther. 2006; 319 (3): 1413-23.

6. Serviddio G, Bellanti F, Giudetti AM, et al. Mitochondrial oxidative stress and respiratory chain dysfunction account for liver toxicity during amiodarone but not dronedarone administration. Free Radic Biol Med. 2011; 51 (12): 2234-42.

7. Golli-Bennour EE, Bouslimi A, Zouaoui O, et al. Cytotoxicity effects of amiodarone on cultured cells. Exp Toxicol Pathol. 2012; 64 (5): 425-30.

8. Schumacher JD, Guo GL. Mechanistic review of drug-induced
P450, conjugating enzymes and nuclear receptors in human hepatoma HepaRG cells. Drug Metab Dispos. 2006; 34 (1): 75-83.

16. Yokoyama $\mathrm{Y}$, Sasaki $\mathrm{Y}$, Terasaki N, et al. Comparison of drug metabolism and its related hepatotoxic effects in HepaRG, cryopreserved human hepatocytes, and HepG2 cell cultures. Biol Pharm Bull. 2018; 41 (5): 722-32.

17. Tomida T, Okamura H, Yokoi T, et al. A modified multiparametric assay using HepaRG cells for predicting the degree of druginduced liver injury risk. J Appl Toxicol. 2017; 37 (3): 382-90.

18. Wu Y, Geng X, Wang J, et al. The HepaRG cell line, a superior in vitro model to L-02, HepG2 and hiHeps cell lines for assessing drug-induced liver injury. Cell Biol Toxicol. 2016; 32 (1): 37-59.

19. McGovern B, Garan H, Ruskin JN. Serious adverse effects of amiodarones. Clin Cardiol. 1984; 7 (3): 131-7.

20. Pessayre D, Fromenty B, Berson A, et al. Central role of mitochondria in drug-induced liver injury. Drug Metab Rev. 2012; 44 (1): 34-87.

21. Anthérieu $S$, Rogue A, Fromenty B, et al. Induction of vesicular steatosis by amiodarone and tetracycline is associated with upregulation of lipogenic genes in heparg cells. Hepatology. 2011; 53 (6): 1895-905.

22. Ye H, Nelson LJ, Gómez del Moral M, et al. Dissecting the molecular pathophysiology of druginduced liver injury. World $J$ Gastroenterol. 2018; 24 (13): 1373-85.

23. Yuan L, Kaplowitz N. Mechanisms of drug induced liver injury. Clin Liver Dis. 2013; 17 (4): 507-18.

24. Iorga A., Dara L. Cell death in drug-induced liver injury. Adv Pharmacol. 2019; 85: 31-74.

25. Ali SE, Waddington JC, Park BK, et al. Definition of the Chemical and Immunological Signals Involved in Drug-Induced Liver Injury. Chem Res Toxicol. 2020; 33 (1): 61-76.

26. Bognar Z, Fekete K, Antus C, et al. Desethylamiodarone - A metabolite of amiodarone - Induces apoptosis on T24 human bladder cancer cells via multiple pathways. PLoS One. 2017; 12 (12): e0189470.

27. Steinberg E, Fluksman A, Zemmour C, et al. Low dose amiodarone reduces tumor growth and angiogenesis. Sci Rep. 2020; 10 (1): 18034.

28. Abdulkhaleq $\mathrm{F}$, Alhussainy $\mathrm{T}$, Badr $\mathrm{M}$, et al. Antioxidative stress effects of vitamins C, E, and B12, and their combination can protect the liver against acetaminophen-induced hepatotoxicity in rats. Drug Des Devel Ther. 2018; 12: 3525-33. steatohepatitis. Toxicol Appl Pharmacol. 2015; 289 (1): 40-7.

9. Grünig D, Duthaler U, Krähenbüh S. Effect of Toxicants on Fatty Acid Metabolism in HepG2 Cells. Front Pharmacol. 2018; 9: 257.

10. Erez N, Hubel E, Avraham R, et al. Hepatic amiodarone lipotoxicity is ameliorated by genetic and pharmacological inhibition of endoplasmatic reticulum stress. Toxicol Sci. 2017; 159 (2): 402-12.

11. Durukan AB, Erdem B, Durukan E, et al. May toxicity of amiodarone be prevented by antioxidants? A cell-culture study. J Cardiothorac Surg. 2012; 7 (1): 61.

12. Galli F, Azzi A, Birringer M, et al. Vitamin E: Emerging aspects and new directions. Free Radic Biol Med. 2017; 102: 16-36.

13. Chughlay MF, Kramer N, Spearman CW, et al. N-acetylcysteine for non-paracetamol drug-induced liver injury: a systematic review. Br J Clin Pharmacol. 2016; 81: 1021-9.

14. Anstee QM, Day CP. S-adenosylmethionine (SAMe) therapy in liver disease: A review of current evidence and clinical utility. J Hepatol. 2012; 57 (5): 1097-109.

15. Aninat C, Piton A, Glaise D, et al. Expression of cytochromes $\mathrm{P} 450$, conjugating enzymes and nuclear receptors in human hepatoma HepaRG cells. Drug Metab Dispos. 2006; 34 (1): 75-83.

16. Yokoyama $\mathrm{Y}$, Sasaki $\mathrm{Y}$, Terasaki N, et al. Comparison of drug metabolism and its related hepatotoxic effects in HepaRG, cryopreserved human hepatocytes, and HepG2 cell cultures. Biol Pharm Bull. 2018; 41 (5): 722-32. 
17. Tomida T, Okamura H, Yokoi T, et al. A modified multiparametric assay using HepaRG cells for predicting the degree of druginduced liver injury risk. J Appl Toxicol. 2017; 37 (3): 382-90.

18. Wu Y, Geng X, Wang J, et al. The HepaRG cell line, a superior in vitro model to L-02, HepG2 and hiHeps cell lines for assessing drug-induced liver injury. Cell Biol Toxicol. 2016; 32 (1): 37-59.

19. McGovern B, Garan H, Ruskin JN. Serious adverse effects of amiodarones. Clin Cardiol. 1984; 7 (3): 131-7.

20. Pessayre D, Fromenty $B$, Berson A, et al. Central role of mitochondria in drug-induced liver injury. Drug Metab Rev. 2012; 44 (1): 34-87.

21. Anthérieu S, Rogue A, Fromenty B, et al. Induction of vesicular steatosis by amiodarone and tetracycline is associated with upregulation of lipogenic genes in heparg cells. Hepatology. 2011; 53 (6): 1895-905.

22. Ye H, Nelson LJ, Gómez del Moral M, et al. Dissecting the molecular pathophysiology of druginduced liver injury. World $J$ Gastroenterol. 2018; 24 (13): 1373-85.
23. Yuan L, Kaplowitz N. Mechanisms of drug induced liver injury. Clin Liver Dis. 2013; 17 (4): 507-18.

24. Iorga A., Dara L. Cell death in drug-induced liver injury. Adv Pharmacol. 2019; 85: 31-74.

25. Ali SE, Waddington JC, Park BK, et al. Definition of the Chemical and Immunological Signals Involved in Drug-Induced Liver Injury. Chem Res Toxicol. 2020; 33 (1): 61-76.

26. Bognar Z, Fekete K, Antus C, et al. Desethylamiodarone - A metabolite of amiodarone - Induces apoptosis on T24 human bladder cancer cells via multiple pathways. PLoS One. 2017; 12 (12): e0189470.

27. Steinberg E, Fluksman A, Zemmour C, et al. Low dose amiodarone reduces tumor growth and angiogenesis. Sci Rep. 2020; 10 (1): 18034.

28. Abdulkhaleq F, Alhussainy $T$, Badr M, et al. Antioxidative stress effects of vitamins $C, E$, and B12, and their combination can protect the liver against acetaminophen-induced hepatotoxicity in rats. Drug Des Devel Ther. 2018; 12: 3525-33. 